УДК 81'27

DOI: 10.33184/YVDK-2021-04-30.28

Е.А. Мельникова (асn. ОГУ, г. Оренбург)

\title{
«СВОЙ» И «ЧУЖОЙ» В ПОЛИКУЛЬТУРНОМ ВЗАИМОДЕЙСТВИИ
}

В статье проводится теоретический анализ понимания «своего» $u$ «чужого» в поликультурном взаимодействии. Выделяются объективные и субъективные факторы, влияющие на его содержание и направленность. C использованием возможностей корпусной лингвистики выявляются основные компоненты семантических полей понятий "Свой» $и$ «Чужой». Подчеркивается важность медиапространства поликультурного региона в поддержании эфффективной межкультурной коммуникации.

Ключевые слова: поликультурное взаимодействие, межкультурная коммуникация, «свой» $и$ «чужой», медиапространство.

In the article a theoretical analysis of the understanding of «his» and «alien» in the multicultural interaction is carried out. Objective and subjective factors are identified that affect its content and direction. Using the possibilities of corpus linguistics, the main components of semantic fields of concepts «Own» and «Alien» are identified. The importance of the media space of the multicultural region in maintaining effective intercultural communication is emphasized.

Key Words: multicultural interaction, intercultural communication, «own» and «alien», media space.

Языковая карта Оренбургского региона складывалась в ходе социокультурной трансформации и модернизации традиционного уклада жизни народов, населяющих данный регион, что является показателем изначального многонационального состава его населения [Просвиркина 2006]. Под термином «национальность» мы понимаем «принадлежность 
индивида к определенной этнической группе, отличающейся особенностями языка, культуры, психологии, традиций, обычаев, образа жизни, в составе государства» [Жукова 2013: 264].

Цель данной статьи - провести анализ понимания «Своего» и «Чужого» в поликультурном взаимодействии на основе анализа компонентов семантических полей этих понятий.

Для выявления компонентов семантических полей «Своего» и «Чужого» в поликультурном взаимодействии «Свой» и «Чужой» нами разработан алгоритм, состоящий из трех этапов, с использованием возможностей корпусной лингвистики: 1) составление выборки определений, извлеченных из 32 анкет, полученных в ходе группового сплошного анкетирования студентов разных национальностей, обучающихся в Оренбургском государственном университете; 2) извлечение из определений ключевых слов с помощью компьютерной программы полного семантического анализа онлайн на сайте https:/advego.com/text/seo/; под извлечением ключевых слов понимается операция, на вход которой подаются определения «Свой» и «Чужой», а на выходе - результат их обработки составленный список ключевых слов, словосочетаний; 3) анализ выделенных ключевых слов, составление инвариантных семантических полей понятий «Свой» и «Чужой». За основу последовательности выполнения действий принят алгоритм, разработанный И.Ю. Моисеевой [Моисеева 2017].

Рассмотрим результаты изучения ключевых слов, формирующих семантическое поле «Свой», полученные на втором этапе исследования в соответствии с алгоритмом.

В программу семантического анализа текста введены 32 определения понятий «Свой». Приведем примеры некоторых определений понятия «Свой», полученных в ходе анкетирования: человек, который чувствует себя комфортно в обществе различных культур; человек, который вырос в этом регионе, чувствует себя комфортно здесь; преобладающяая нащия; человек, который чувствует себя хорошо в том обществе, в котором он живет; представитель, преобладающий по численности национальности; личность, которая является частью одного из культурных сочиумов, т.е. знает язык, культуру; человек, имеющий те же взгляды, обычаи, который знает свою культуру и историю родного места; представитель 
одной из культур региона; человек, который погружен в культуру, соблюдает ее нормы; человек, принадлежащций определенной национальности; человек, который относится к культурам всех или большинства народов, проживающих в регионе; это привычное и понятное всем народам и культурам региона (орфография и пунктуация респондентов сохранена).

В результате обработки данных программа выделила ключевые слова, образующие семантическое поле данного понятия. Полученные результаты занесены в таблицу (см. таблицу 1).

Таблица 1 - Ключевые слова, образующие семантическое поле понятия «Свой» (фрагмент)

\begin{tabular}{|c|c|c|}
\hline Слово & Количество & Частота, \% \\
\hline культура & 7 & 6.80 \\
\hline регион & 4 & 3.88 \\
\hline чувствовать & 3 & 2.91 \\
\hline 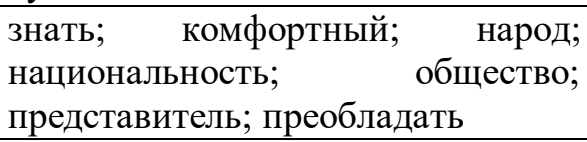 & 2 & 1.94 \\
\hline 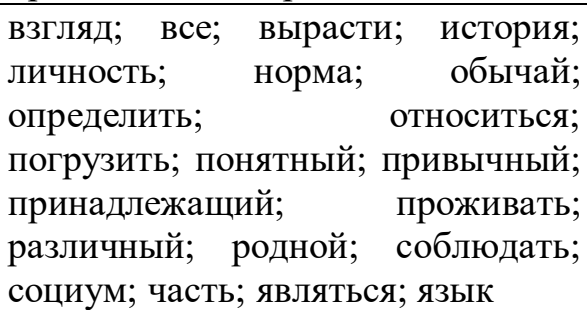 & 1 & 0.97 \\
\hline
\end{tabular}

Как видно из таблицы 1, наиболее частотными ключевыми словами являются: культура; регион; чувствовать; знать; комфортный; народ; национальность; общество; представитель; преобладать. Результаты позволяют сделать вывод о том, что при определении «Своего» студенты придают первостепенное значение знанию культуры региона, в котором они проживают, комфортному существованию, принадлежности к народу, национальности, которые преобладают по численности в регионе. Анализ наименее частотных ключевых слов показал, что для человека такие понятия как привычный, понятный, погруженный в определенный социум, проживающий в определенном регионе, 
являются важными, но не основополагающими. В данную классификацию попало и существительное «язык». Априори предполагалось, что знание языка, как одного из компонентов культуры, респонденты отнесут к числу значимых слов. Полученные результаты могут быть обоснованы сменой менталитета, мобильностью людей, глобализацией, и как следствие интеграцией.

Рассмотрим результаты изучения ключевых слов, формирующих семантическое поле «Чужой», полученные на втором этапе исследования в соответствии с алгоритмом.

В программу семантического анализа текста введены 32 определения понятий «Чужой». Приведем примеры некоторых определений понятия «Чужой», полученных в ходе анкетирования: которому сложно находиться в обстановке, не соответствующей его представлениям о мире. Ему сложно жить в обществе различных культур; вырос в другом месте, он не знает местных люде, ему здесь не комфортно; не комфортно ошушаюший себя в общзестве, чувствует непонимание с окружающими, испытывает трудности в коммуникации; нация, не характерная данному региону, или та, которой меньше всего; представитель культуры другой наџии; не является частью одного из культурных социумов, т.е. не знает язык, культуру; не принимает традиции и обычаи никакой нации; представитель культуры другого региона; сохраняет свою национальную культуру, традиции и нормы поведения в другой культуре; относящийся $\kappa$ другой национальности; не относится к культурам местных народностей, отдаленный от них; это непривычное и непонятное, неприемлемое для всех культур региона (орфография и пунктуация респондентов сохранена).

В результате обработки данных программа выделила ключевые слова, образующие семантическое поле данного понятия. Полученные результаты занесены в таблицу (см. таблицу 2).

Таблица 2 - Ключевые слова, образующие семантическое поле понятия «Чужой» (фрагмент)

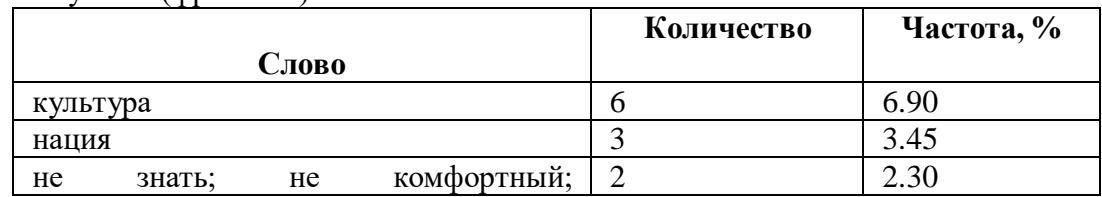




\begin{tabular}{|l|l|l|}
\hline $\begin{array}{l}\text { представитель; регион; традиция; } \\
\text { вырасти }\end{array}$ & \\
\hline национальный; не относиться; не & 1 & 1.15 \\
понимание; не принимать; не & & \\
характерный; не являться; никакой; & & \\
норма; общество; обычай; окружающее; & & \\
отдалить; относиться; ощущать; & & \\
поведение; сохранять; социум; & & \\
трудность; часть; чувствовать; чужой; & & \\
язык &
\end{tabular}

Как видно из таблицы 2, наиболее частотными ключевыми словами при определении «Чужого» являются: культура; нация; не знать; не комфортный; представитель; регион; традиция; вырасти. Примечательно, что как для определения «Своего», так и для определения «Чужого» респонденты на первое место ставят культуру, в первом случае - знание культуры, во втором - ее незнание. Данный результат может быть объяснен тем, что культура является искусственным средством человеческой жизнедеятельности, без которой существование любого человека немыслимо. Следующее частотное ключевое слово, которое используется для определения обоих понятий, выступает «комфортный» и его противопоставление - отрицательная форма «не комфортный», подчеркивая еще раз значимость субъективного восприятия условий жизни человека. При анализе наименее частотных ключевых слов для определения «Чужого» прослеживается противоположная тенденция. Чужой - это человек, который не знает и не соблюдает обычаи, не принимает нормы социума, не знает язык, на котором говорят в данном регионе. Однако если он чувствует себя комфортно, то все эти характеристики нивелируются в поликультурном регионе.

В современном медиатизированном мире все процессы, происходящие в поликультурном регионе, так или иначе, находят свое отражение в медиапространстве. Так, Н.Б. Зазаева делает акцент на том, что средства массовых коммуникаций в современном мире, определяя контекст, направленность восприятия информации, межкультурные коды, влияют не только на общественное мнение, но и на представления отдельного индивида в области межэтнических взаимодействий [Зазаева 2013]. 
Однако И.В. Челышева подчеркивает функциональную двойственность СМИ. Так, наряду с предоставлением расширяющейся коммуникационной средой широких возможностей получения практически любой информации, современное медиапространство заключает в себе серьезные информационные риски и медиаугрозы, связанные со случаями распространения экстремизма, ксенофобии, межэтнической нетерпимости [Челышева 2019]. Автор объясняет этот феномен целым рядом объективных обстоятельств, связанных с глобализационными процессами, обострением геополитической обстановки, активной миграцией, существенными социокультурными изменениями.

В данном контексте важной является роль медиапространства в регулировании взаимодействия индивидов в поликультурном регионе.

\section{ЛИТЕРАТУРА}

1. Ж Жукова И.Н. Словарь терминов межкультурной коммуникации /И.Н.Жукова [идр.].-Москва:Флинта:Наука, 2013.-628 с.

2. Зазаева Н.Б. Роль СМИ в формировании межэтнической толерантности в современной России // Вестник ПАГС, 2013, №5(38). [Электронный ресурс]. URL: $\quad$ hitps://cyberleninkarv/article/n/rol-smi-v-formirovanii-mezhetnicheskoytolerantnosti-v-sovremennoy-rossii (дата обращения: 05.03.2021).

3. Моисеева И. Ю., Мельникова Е. А. Формирование семанпического поля «полиязычие» в отечественной и зарубежной науке / Филологические науки. Вопросы теории и практики, 2017, №12-4 (78). [Электронный ресурс]. URL: hitps//cyberleninka.rv/article/n/formirovanie-semanticheskogo-polya-poliyazychie-votechestvennoy-i-zarubezhnoy-nauke (дата обращения: 28.02.2021).

4. Просвиркина И.И. Формирование толерантной речевой коммуникации как одна из основньх задач в обучении русскому языку // Вестник СамГУ, 2006, №10-2. [Электронный ресурc]. URL: hitps://cyberleninka.nwarticle/n/formirovanietolerantnoy-rechevoy-kommunikatsii-kak-odna-iz-osnovnyh-zadach-v-obucheniirusskomu-yazyku (дата обращения: 23.03.2021).

5. Чельшева И.В. Проблема формирования межэтнической толерантности студенчества и риски современного медиапространства // Crede Experto: транспорт, общество, образование, язык, 2019, №2. [Электронный ресурс]. URL: https:/cyberleninka.ru/article/n/problema-formirovaniya-mezhetnicheskoy-tolerantnostistudenchestva-i-riski-sovremennogo-mediaprostranstva (дата обращения: 21.03.2021).

(С) МельниковаЕ.А., 2021 г. 